\title{
DIMENSI SERAT DAUN Pandanus tectorius Park. SEBAGAI BAHAN BAKU PRODUK SERAT ALAM
}

\section{(Fiber Dimension of Pandanus tectorius Park. Leaf for Natural Fiber Product Raw Material)}

\author{
Fitra Haryadi $^{1}$, Cicilia Maria Erna Susanti ${ }^{1 凶}$ dan Endra Gunawan ${ }^{1}$ \\ Jurusan Kehutanan, Fakultas Kehutanan Universitas Papua Manokwari, Papua Barat, \\ 98314. Tlp/Fax: +62986211065. \\ $\bowtie$ Penulis Korespondensi: Email: c.susanti@unipa.ac.id \\ Diterima: 05 Mar 2017| Disetujui: 01 Apr 2017
}

\begin{abstract}
Abstrak
Kebutuhan serat terus meningkat dan memiliki peran penting dalam menopang kebutuhan manusia saat ini. Tujuan dari penelitian ini yaitu untuk mengetahui dimensi serat daun $P$. tectorius Park. dan nilai manfaat lanjutannya. Metode yang digunakan yaitu deskriptif dengan teknik observasi laboratorium terhadap sampel uji. Dua sampel daun dari pohon yang berbeda diambil berdasarkan perbedaan karakteristik ekologinya, yaitu hutan pantai dan hutan pulau. Pengukuran serat yang meliputi panjang, diameter, tebal, diameter lumen, proses maserasi dan nilai turunannya dikaji. Hasil penelitian menunjukkan rata-rata panjang serat daun Pandanus pada lokasi Amban Pantai sebesar 0.957, sementara di pulau Mansinam sebesar 1.210. Nilai rata-rata dimensi serat daun Pandanus di lokasi Amban Pantai sebesar 0,0073, sementara di lokasi pulau Mansinam sebesar 0.0151. Rata-rata nilai diameter lumen daun Pandanus pada lokasi Amban Pantai yaitu 0.0073, dan di lokasi pulau Mansinam sebesar 0.0081. Nilai rata-rata tebal dinding serat sebesar 0.0032 untuk lokasi Amban Pantai dan untuk lokasi pulau mansinam sebesar 0.0035. Selain itu, nila dimensi serat ini cukup potensial digunakan sebagai bahan baku industri kertas, tekstil dan biokomposit.
\end{abstract}

Kata Kunci: Dimensi serat, Pandanus tectorius, serat, produk turunan serat.

\section{Abstract}

The need of fiber has been rising over time and playing an important role in the society. This study was aimed to unveil fiber dimension of P. tectorius Park leaf as well as its derivative potential uses. Method that used was descriptive through laboratory analysis of the tested samples. Two leaves samples from different ecological growth habitat were applied, in Amban Pantai and another one as from the island. Fibers have been measured for its length, diameter, thickness, lumen, maceration process, and its derivative value were measured. The result showed that the average of fiber length from Pandanus leaves was 0.957 in Amban Pantai, while in the Mansinam island was 1.210. The average of fiber dimension was 0,0073 in Amban Pantai, while in the Mansinam Island was 0.0151. The average of lumen diameter was 0.0073 in Amban Pantai, while in the Mansinam island was 0.0081. The average of fiber thickness was 0.0032 in Amban Pantai, while in the Mansinam island was 0.0035. Moreover, the fiber dimension was quite potential that intended for a number of derivative products such as pulp and paper, textile, and biocomposite. Keywords: Fiber dimension, Pandanus tectorius, fiber, derivative fiver products. 


\section{PENDAHULUAN}

Penggunaan serat alam dewasa ini makin berkembang, dikarenakan jumlah yang banyak, murah, ramah lingkungan serta yang menjadi perkembangan terbaru yaitu serat alam dapat dimanfaatkan sebagai material penguat (bahan komposit). Jenis-jenis serat alam yang digunakan sangat beragam, bahkan beberapa produk dari serat alam merupakan gabungan antara jenis serat alam antara yang satu dan lainnya serta gabungan antara serat alam dan serat buatan. Meski kekuatan dari serat alam mempunyai kekuatan yang rendah dibandingkan dengan serat buatan, namun dengan keunggulan yang lebih ramah lingkungan tetap menjadikan pemanfaatan serat alam lebih beragam. Salah satu pemanfaatan serat alam adalah dengan menggunakan serat dari daun Pandanus.

Pandanus adalah tumbuhan monokotil termasuk dalam ordo Pandanales dan merupakan famili dari kelompok Pandanaceae, memiliki hampir sebanyak 600-700 jenis dan sebanyak 500 jenis terdapat di New Guinea (Stone 1983). Tumbuhan ini tumbuh di pantaipantai daerah tropis, dicirikan dengan daun yang memanjang, tepinya berduri, akarnya besar dan memiliki akar tunjang yang berfungsi menopang tumbuhan ini dan buahnya tersusun dalam karangan berbentuk membulat (Kemeray 2013). Salah satu spesies dari genus Pandanus yang ditemui banyak tumbuh di kawasan Papua Barat adalah Pandanus tectorius Park. Masyarakat lokal telah memanfaatkan tumbuhan ini; batangnya dapat digunakan sebagai tiang penyangga; daunnya dapat digunakan sebagai penyedap masakan maupun sebagai bahan ramuan obat tradisional; buah segar digunakan sebagai obat; bijinya dapat dimakan seperti kelapa (Sinaga dan Irbayanti 2004).

Khusus pada daun $P$. tectorius Park. selain pemanfaatan tersebut, dapat juga dimanfaatkan sebagai bahan anyaman (tikar, tas, topi, jas hujan dan lainlain). Produk-produk ini merupakan produk yang hanya memanfaatkan bagian dari daun yang dimanfaatkan oleh masyarakat. Dengan adanya serat alami yang terdapat pada daun $P$. tectorius Park. tentunya pemanfaatan ini akan menjadi lebih beragam dan bernilai. Berdasarkan uraian tersebut, timbul pemikiran untuk mengetahui dimensi serat dari daun $P$. tectorius Park. Penelitian ini bertujuan untuk mengetahui dimensi serat daun $P$. tectorius Park. yang meliputi panjang serat, diameter serat, tebal dinding serat, dan diameter lumen dan potensi serat daun $P$. tectorius Park. sebagai bahan baku produk serat alam. Hasil penelitian ini diharapkan dapat memberi informasi mengenai dimensi serat dari daun $P$. tectorius Park. sehingga seratnya dapat menjadi produk-produk serat alam yang lebih ramah lingkungan.

\section{METODE PENELITIAN}

Penelitian ini dilaksanakan di laboratorium teknologi hasil hutan dan silvikultur Fakultas Kehutanan Universitas Papua pada bulan Juni 2014. Metode yang digunakan dalam penelitian ini adalah metode deskriptif dengan teknik observasi. Pengambilan sampel dilakukan dengan memotong daun sebanyak 3 helai dari pohon $P$. tectorius Park. dengan tinggi 2-3 meter dengan diameter diatas $11 \mathrm{~cm}$. Daun yang diambil terletak di 3 bagian yaitu bagian bawah pohon (daun tua), tengah pohon 
(setengah muda), dan dekat pucuk pohon (daun tunas/muda). Panjang daun yang akan dijadikan sampel yaitu minimal 50 $\mathrm{cm}$ dan lebar daun minimal $3,5 \mathrm{~cm}$. Habitat dari daun yang akan dijadikan sampel adalah daerah vegetasi hutan pantai (pantai Amban) dan di pulau Mansinam dengan kondisi tekstur tanah yang berpasir. Deskripsi pohon untuk sampel yang tumbuh di Amban Pantai mempunyai tinggi pohon sekitar 2 meter dan diameter batang sekitar $12 \mathrm{~cm}$. Sedangkan sampel daun yang tumbuh di Pulau Mansinam memiliki tinggi pohon sekitar 3 meter dan diameter batang sekitar $15 \mathrm{~cm}$ serta telah berbuah. Kedua pohon ini tumbuh pada keadaan tekstur tanah berpasir. Pada masing-masing daun yang telah dipotong akan dijadikan contoh uji dengan membagi menjadi 6 bagian dan dipotong lurus searah tulang daun dengan lebar maksimal $0,5 \mathrm{~cm}$ dan panjang sesuai dengan panjang daun. Bagian tersebut adalah bagian kiri dekat duri, kiri tengah, kiri dekat tulang daun, bagian kanan dekat duri, kanan tengah dan kanan dekat tulang daun sehingga akan diperoleh 36 bagian untuk 2 pohon dengan lokasi pengambilan yang berbeda.

\section{Proses Maserasi}

Maserasi merupakan metode penghancuran atau penguraian serat sehingga akan diperoleh serat serat tunggal dari daun. Proses maserasi yang digunakan untuk mendapatkan serat daun $P$. tectorius Park. yaitu mengikuti metode Forest Product Laboratory dengan beberapa modifikasi. Langkah kerjanya adalah sebagai berikut:

a. Daun P. tectorius Park dengan lebar maksimal $0,5 \mathrm{~cm}$ dimasukkan dalam wadah gelas. Sebelumnya untuk mempermudah mendapatkan serat, daun Pandanus digerus kedua sisinya atau sisi depan dan belakang daun.

b. Hidrogen peroksida $\left(\mathrm{H}_{2} \mathrm{O}_{2}\right)$ dan asam asetat glasial $\left(\mathrm{CH}_{3} \mathrm{COOH}\right)$ menggunakan metode LPHH yaitu dengan perbandingan 20:1 (Maria, 2001) dimasukkan dalam wadah gelas yang telah berisi potongan daun $P$. tectorius Park.

c. Campuran tersebut dipanaskan hingga 9 jam (Frans 2013) dalam suhu 100 ${ }^{\circ} \mathrm{C}$ atau hingga diperoleh serat daun P. tectorius Park.

d. Serat yang diperoleh dibebas-asamkan dengan menggunakan air destilasi. Bebas asam diuji dengan menggunakan kertas lakmus.

e. Serat bebas asam selanjutnya diberi pewarna safranin, campuran tersebut dibiarkan untuk beberapa saat. Selanjutnya serat yang telah diberi warna (safranin) ditetesi dengan alkohol untuk membuat warna lebih tahan lama.

f. Serat yang diperoleh selanjutnya diukur nilai dimensi seratnya.

\section{Prosedur Pengukuran Serat}

Penentuan jumlah serat yang diamati (N) tergantung dari besarnya variasi panjang serat suatu pohon, dengan patokan bahwa nilai rata-rata tidak memiliki nilai error lebih dari 5\% $(0,05)$. Jumlah serat diukur dalam satu pohon ditetapkan dengan persamaan (Silitonga dkk. 1972 yang disitasi Galugu 2005) sebagai berikut:

$$
\mathbf{N}=4 \mathrm{~S}^{2} / \mathbf{L}^{2}
$$

Dimana:

$\mathrm{N} \quad=$ Jumlah serat yang diukur

$\mathrm{S} \quad=$ Standar deviasi

$\mathrm{L}=$ Nilai rata-rata contoh $\mathrm{x} 0,05$ 
Pengujian serat daun $P$. tectorius Park. dilakukan dengan menghitung dimensi serat yang diukur menggunakan mikroskop. Jumlah serat yang diukur diambil sebanyak 5 (lima) buah secara acak dari 6 pengamatan bagian daun, maka jumlah serat yang diukur sebanyak $5 \times 6=30$ serat per bagian daun. Jumlah daun sebanyak 3 bagian, sehingga total serat yang diukur sebanyak $30 \times 3 \times 2=$ 180 serat.

Selanjutnya data yang diperoleh dihitung standar deviasinya dengan menggunakan persamaan (Silitonga dkk. 1972 yang disitasi Galugu 2005) sebagai berikut:

$$
\mathrm{S}^{2}=\frac{\sum f i x i^{2}-\sum(f i x i)^{2} / n}{n-1} \times 0,05
$$

Sementara nilai $L$ dapat dihitung dengan menggunakan persamaan sebagai berikut:

$$
\mathrm{L}^{2}=\frac{\sum f i x i}{n} \times 0,05
$$

Dimana:

$$
\begin{aligned}
& \mathrm{fi}=\text { frekuensi serat } \\
& \mathrm{xi}=\text { panjang serat } \\
& \mathrm{n}=\text { jumlah serat yang diukur pada } \\
& \text { pengamatan }
\end{aligned}
$$

Hasil perhitungan diperoleh nilai $\mathrm{N}$ adalah 119 serat. Nilai ini lebih kecil daripada (n), maka sampel yang diamati yaitu 180 serat tetap menjadi jumlah serat yang diukur. Selanjutnya dilakukan pengukuran dimensi serat dan data yang dibutuhkan meliputi:

a. Panjang serat diukur menggunakan mikroskop perbesaran 100 kali, yaitu dari ujung serat.

b. Diameter serat diukur menggunakan mikroskop perbesaran 400 kali, yaitu pada kedua ujung serat dan tengah serat kemudian dihitung rata-ratanya.

c. Tebal dinding serat diukur menggunakan mikroskop perbesaran 400 kali, yaitu pada kedua ujung dan tengah serat kemudian dihitung rataratanya.

d. Diameter lumen dihitung menggunakan rumus:

$$
\mathbf{I}=\mathbf{d} \mathbf{- 2} \mathbf{w}
$$

Dimana:

$$
\begin{array}{ll}
\mathrm{I} & =\text { Diameter lumen } \\
\mathrm{D} & =\text { Diameter Serat } \\
\mathrm{W} & =\text { Tebal Dinding Serat }
\end{array}
$$

\section{Penentuan Nilai Turunan Dimensi Serat}

Nilai turunan dimensi serat merupakan perbandingan antara masingmasing komponen dimensi serat yaitu panjang, diameter, tebal dinding serat dan diameter lumen yang terdiri dari Bilangan Muhlsteph, Bilangan Runkel, Daya Tenun, Koefisien Kekakuan dan Nilai Kelenturan (Silitonga dkk. 1972 yang disitasi Galugu 2005). Perhitungan nilai turunan dimensi serat seperti pada Tabel1. 
Tabel 1. Nilai turunan dimensi serat dan cara perhitungannya

\begin{tabular}{lcl}
\hline \multicolumn{1}{c}{ Nilai Turunan Dimensi Serat } & Rumus Perhitungan \\
\hline Bilangan Muhlsteph & $\left(\mathrm{d}^{2}-\mathrm{I}^{2}\right) / \mathrm{d}^{2} \times 100 \%$ \\
Bilangan Runkel & $2 \mathrm{w} / \mathrm{I}$ & \\
Daya Tenun & $\mathrm{P} / \mathrm{d}$ & \\
Koefisien Kekakuan & $\mathrm{w} / \mathrm{d}$ & \\
Nilai Kelenturan & $\mathrm{I} / \mathrm{d}$ & \\
\hline Dimana : & $\mathrm{w} \quad=$ Tebal Dinding Serat \\
$\mathrm{I} \quad=$ Diameter lumen & $\mathrm{P} \quad=$ Panjang serat \\
$\mathrm{d} \quad=$ Diameter Serat & $\mathrm{P}$
\end{tabular}

\section{HASIL DAN PEMBAHASAN}

Panjang Serat

Panjang serat adalah ukuran memanjang serat yang diukur dari ujung satu ke ujung lainnya. Rata-rata panjang serat dari kedua daun yang tumbuh di Amban Pantai dan Pulau Mansinam dapat dilihat pada Tabel 2. Pada daun $P$. tectorius Park. yang berasal dari Amban Pantai memiliki panjang serat yang berkisar antara $0,58 \mathrm{~mm}$ dan $1,98 \mathrm{~mm}$ sedangkan pada daun P. tectorius Park. yang berasal dari Pulau Mansinam memiliki panjang serat yang berkisar antara $0,71 \mathrm{~mm}$ dan $1,96 \mathrm{~mm}$. Panjang serat dari kedua daun yang tumbuh di Amban Pantai dan Pulau Mansinam termasuk dalam kategori serat dengan ukuran sedang (IAWA 1989).

Tabel 2. Rata-rata panjang serat daun P. tectorius Park.

\begin{tabular}{lccc}
\hline Lokasi Pengambilan & Bagian Daun & $\begin{array}{c}\text { Rataan Per Bagian } \\
\text { Daun }(\mathrm{mm})\end{array}$ & $\begin{array}{c}\text { Rataan Per Lokasi } \\
\text { Pengambilan }(\mathrm{mm})\end{array}$ \\
\hline Amban Pantai & Dekat pucuk & 0,8876 & 0,957 \\
& Tengah & 0.969 & \\
& Bawah & 1,0145 & 1,210 \\
Pulai Mansinam & Dekat pucuk & 1,1824 & \\
& Tengah & 1,2152 & \\
& Bawah & 1,2317 & \\
\hline
\end{tabular}

Pada Tabel 2. dapat dilihat bahwa rata-rata panjang serat per bagian dari daun P. tectorius Park. yang berasal dari Pulau Mansinam memiliki serat yang lebih panjang dibandingkan dengan daun yang berasal dari Amban Pantai. Hal ini diduga karena terdapat perbedaan usia pohon yang dijadikan sampel daun pohon di Pulau Mansinam lebih dewasa daripada pohon di Amban Pantai karena $P$. tectorius Park. yang tumbuh di Pulau Mansinam telah berbuah. Perbedaan ini sesuai dengan pernyataan oleh Husodo (1997) yang mengatakan bahwa variasi dari dimensi serat suatu tumbuhan dipengaruhi oleh umur pohon.

Panjang serat daun yang berasal dari Amban Pantai maupun Pulau Mansinam 
dari bagian dekat pucuk hingga ke bagian bawah daun, rata-rata panjang dimensi seratnya cenderung bertambah. Hal ini dipengaruhi oleh umur daun dimana pada daun yang sudah tua (bagian bawah) cenderung memiliki serat yang lebih panjang dibandingkan bagian lainnya. Hal ini diduga karena daun tua telah mengalami proses pertumbuhan sel yang lebih lama (telah memasuki tahap akhir perkembangan sel) dibandingkan daun muda yang proses pertumbuhan dan perkembangan selnya masih dalam tahap berkembang. Namun pada daun setengah tua (bagian tengah) memiliki panjang serat yang hampir sama dengan daun bagian tua. Dengan demikian dapat dikatakan bahwa daun yang tua maupun daun yang setengah tua memiliki kualitas panjang serat yang hampir sama dalam pemanfaatannya untuk produk serat alam.

\section{Diameter Serat}

Diameter serat merupakan ukuran kearah melebar serat mulai dari tepi satu ke tepi lainnya. Rata-rata diameter serat dari kedua daun yang tumbuh pada tempat berbeda dapat dilihat pada Tabel 3.

Tabel 3. Rata-rata dimensi serat daun P. tectorius Park.

\begin{tabular}{cccc}
\hline Lokasi Pengambilan & Bagian Daun & $\begin{array}{c}\text { Rataan Per Bagian } \\
\text { Daun }(\mathrm{mm})\end{array}$ & $\begin{array}{c}\text { Rataan Per Lokasi } \\
\text { Pengambilan }(\mathrm{mm})\end{array}$ \\
\hline Amban Pantai & Dekat pucuk & 0,0141 & 0,0138 \\
& Tengah & 0,0137 & \\
Pulai Mansinam & Bawah & 0,0126 & 0,0151 \\
& Dekat pucuk & 0,0159 & \\
& Tengah & 0,0152 & \\
& Bawah & 0,0143 & \\
\hline
\end{tabular}

Pada daun $P$. tectorius Park. yang berasal dari Amban Pantai memiliki diameter serat yang berkisar antara 0,01 mm dan 0,0175 $\mathrm{mm}$ sedangkan pada daun $P$. tectorius Park yang berasal dari Pulau Mansinam memiliki diameter serat yang berkisar antara $0,0075 \mathrm{~mm}$ dan 0,0375 $\mathrm{mm}$. Diameter serat dari kedua daun yang tumbuh di Amban Pantai dan Pulau Mansinam termasuk dalam kategori serat dengan ukuran sedang (Klemm dalam Casey, 1960 yang disitasi Husodo 1997). Pada Tabel 2, rata-rata diameter serat dari daun P. tectorius Park. Yang tumbuh pada daerah Amban Pantai maupun Pulau Mansinam cenderung menurun dari bagian dekat pucuk hingga ke bagian bawah. Hal ini diduga karena pada daun muda masih mengalami proses pembentukan sel sehingga diameter seratnya cenderung lebih besar dibandingkan bagian lainnya.

\section{Diameter Lumen}

Diameter lumen adalah ukuran besarnya rongga sel (lumen) yang terletak diantara dinding sel yang satu dengan dinding sel lainnya. Rata-rata diameter lumen dari kedua daun yang tumbuh pada tempat berbeda dapat dilihat pada Tabel 4. 
Tabel 4. Rata-rata diameter lumen P. tectorius Park.

\begin{tabular}{cccc}
\hline Lokasi Pengambilan & Bagian Daun & $\begin{array}{c}\text { Rataan Per Bagian } \\
\text { Daun }(\mathrm{mm})\end{array}$ & $\begin{array}{c}\text { Rataan Per Lokasi } \\
\text { Pengambilan }(\mathrm{mm})\end{array}$ \\
\hline Amban Pantai & Dekat pucuk & 0,0071 & 0,0073 \\
& Tengah & 0,0073 & \\
Pulai Mansinam & Bawah & 0,0076 & 0,0081 \\
& Dekat pucuk & 0,0098 & \\
& Tengah & 0,0082 & \\
& Bawah & 0,0063 & \\
\hline
\end{tabular}

Pada daun $P$. tectorius Park. yang berasal dari Amban pantai memiliki diameter lumen yang berkisar antara $0,0025 \mathrm{~mm}$ dan $0,00125 \mathrm{~mm}$ sedangkan pada daun $P$. tectorius Park. yang berasal dari Pulau Mansinam memiliki diameter lumen yang berkisar antara $0,0025 \mathrm{~mm}$ dan $0,0275 \mathrm{~mm}$. Pada Tabel 3, rata-rata diameter lumen dari daun $P$. tectorius Park. yang tumbuh pada daerah Amban pantai cenderung bertambah dari bagian dekat pucuk hingga ke bagian bawah. Hal ini diduga karena pengaruh habitat tumbuh sehingga diameter lumen cenderung bertambah. Sedangkan ratarata diameter lumen dari daun $P$. tectorius Park. Yang tumbuh pada daerah Pulau Mansinam cenderung berkurang dari bagian dekat pucuk hingga ke bagian bawah yang diduga disebabkan oleh pada akhir periode pertumbuhan terbentuk trakeid dengan diameter lumen kecil (Fengel dan Wegener 1995 yang disitasi Renyaan 2009).

\section{Tebal Dinding Serat}

Tebal dinding serat adalah selisih antara setengah dari diameter serat dan diameter lumen. Rata-rata tebal dinding serat dari kedua daun yang tumbuh pada tempat berbeda dapat dilihat pada Tabel 5 .

Tabel 5. Rata-rata tebal dinding serat daun P. tectorius Park.

\begin{tabular}{lccc}
\hline Lokasi Pengambilan & Bagian Daun & $\begin{array}{c}\text { Rataan Per Bagian } \\
\text { Daun }(\mathrm{mm})\end{array}$ & $\begin{array}{c}\text { Rataan Per Lokasi } \\
\text { Pengambilan }(\mathrm{mm})\end{array}$ \\
\hline Amban Pantai & Dekat pucuk & 0,0033 & 0,0032 \\
& Tengah & 0,0033 & \\
Pulai Mansinam & Bawah & 0,0032 & 0,0035 \\
& Dekat pucuk & 0,0038 & \\
& Tengah & 0,0035 & \\
& Bawah & 0,0031 & \\
\hline
\end{tabular}

Pada daun $P$. tectorius Park. yang berasal dari Amban Pantai memiliki tebal dinding serat yang berkisar antara 0,0025 $\mathrm{mm}$ dan $0,0075 \mathrm{~mm}$ sedangkan pada daun $P$. tectorius Park. yang berasal dari Pulau Mansinam memiliki tebal dinding serat yang berkisar antara $0,0025 \mathrm{~mm}$ dan $0,0075 \mathrm{~mm}$. Pada Tabel 4 dan 5, klasifikasi dari tebal dinding serat pada daun $P$. tectorius Park. adalah tipis (tebal dinding serat agak kecil dari diameter lumen) (Butterfields dan Meyland, 1980 
yang disitasi Husodo 1997). Semua bagian daun yang tumbuh pada dua habitat yang berbeda mempunyai rata-rata tebal dinding serat termasuk dalam klasifikasi tipis. Dari hasil yang diperoleh di Tabel 4, ratarata tebal dinding serat dari daun $P$. tectorius Park. yang tumbuh pada daerah Amban pantai maupun yang tumbuh di Pulau Mansinam cenderung berkurang dari bagian dekat pucuk hingga ke bagian bawah.

\section{Nilai Turunan Dimensi Serat}

Nilai turunan dimensi serat adalah perbandingan antara masing-masing komponen dimensi serat yaitu panjang, diameter, tebal dinding serat dan diameter lumen. Nilai turunan dimensi serat dari dua lokasi pengambilan sampel disajikan pada

Tabel

6.

Tabel 6. Nilai turunan dimensi serat daun P. tectorius Park.

\begin{tabular}{lcc}
\hline \multirow{2}{*}{ Turunan Dimensi Serat } & \multicolumn{2}{c}{ Lokasi Pengambilan } \\
\cline { 2 - 3 } & Amban Pantai & Pulau mansinam \\
\hline Bilangan Muhlsteph & 72,02 & 71,22 \\
Bilangan Runkel & 0,877 & 0,864 \\
Daya Tenun & 69,35 & 80,13 \\
Koefisien Kekauan & 0,232 & 0,232 \\
Nilai Kelenturan & 0,529 & 0,536 \\
\hline
\end{tabular}

Hasil yang diperoleh pada Tabel 6, berdasarkan kriteria persyaratan bahan baku pulp dan kertas pada Tabel 7 (Departemen Pertanian 1976 yang disitasi Galugu 2005), nilai Bilangan Mulsteph termasuk dalam klasifikasi kelas III dengan nilai 60-80, Bilangan Runkel termasuk dalam klasifikasi kelas III dengan nilai 0,5-1, Daya Tenun termasuk dalam Klasifikasi kelas III dengan nilai 40-70 untuk daun yang diambil dari Amban Pantai dan kelas II dengan nilai 70-90 untuk daun yang diambil dari Pulau Mansinam, Koefisien Kekakuan termasuk dalam klasifikasi kelas IV dengan nilai $>0,2$ dan Nilai Kelenturan termasuk dalam klasifikasi kelas III dengan nilai 0,4-0,6. Menurut Tarigan (2009), penentuan nilai turunan dimensi serat dimaksudkan untuk:

1. Bilangan Muhlsteph akan memberikan sifat kekuatan ledak dan kekuatan tarik pulp yang tinggi.
Sebaliknya serat yang mempunyai dinding sel tebal dan diameter kecil cenderung akan mempertahankan bentuknya selama pembentukan lembaran, sehingga luas kontak antar sel kecil yang mengakibatkan kekutatan tarik dan sobek rendah.

2. Bilangan runkel jika rendah, berarti memiliki dinding sel tipis dan lumen lebar, pada waktu pembentukan lembaran serat akan membentuk pita sehingga ikatan antar serat tinggi. Sifat kertas yang dihasilkan mempunyai kekuatan yang baik dan tembus cahaya.

3. Daya tenun (Felting Power Slenderness) sangat berpengaruh terhadap kekuatan sobek kertas. Makin tinggi daya tenun, maka kekuatan sobek makin tinggi pula.

4. Koefisien Kekakuan (Coeficient of rigidity) berbanding terbalik dengan sifat kekuatan tarik kertas, artinya 
semakin tinggi koefisien kekakuan, maka semakin rendah kekuatan tarik dari kertas begitupun sebaliknya.

5. Nilai kelenturan (Flexibility Ratio) tinggi berarti serat tersebut mempunyai tebal dinding yang tipis dan mudah berubah bentuk. Kemampuan berubah bentuk menyebabkan persinggungan antara permukaan serat lebih leluasa sehingga terjadi ikatan serat yang lebih baik yang akan menghasilkan lembaran pul dengan kekuatan baik. Makin tinggi nilai kelenturan, maka kekuatan panjang putus yang dihasilkan makin tinggi.

\section{Produk Serat Alam yang Potensial Dibuat Menggunakan Daun Pandanus tectorius Park.}

Pemanfaatan tumbuhan penghasil serat alam pada proses lebih lanjut dalam menghasilkan berbagai produk, mempunyai berbagai kriteria dalam pengelolaannya. Salah satu kriteria tersebut adalah dimensi serat. Berdasarkan kriteria dimensi serat, daun P. tectorius Park. memiliki panjang serat yang termasuk kategori serat dengan ukuran sedang, diameter serat dengan ukuran serat sedang, dan tebal dinding serat yang tipis dimana diameter lumen lebih besar daripada tebal dinding serat. Menurut Kemeray (2013), morfologi dari daun P. tectorius Park. yaitu daun spiral tersusun dalam 3 baris dan berkerombol di pucuk cabang, panjang keseluruhan antara 131-136 cm, lebar pangkal 6-6,1 $\mathrm{cm}$, tengah $5-7 \mathrm{~cm}$, ujung 1,6-1,8 cm, jarak antar duri 1-3 cm, berwana hijau tua, susunan berselang-seling dan permukaan halus. Secara anatomi, daun $P$. tectorius Park. memiliki jumlah stomata relatif banyak dengan tipe stomata anomocytic dan sel epidermis yang memiliki kerapatan per satuan luas tinggi (Kemeray, 2013). Keadaan ini yang membuat masyarakat sering menggunakan daun $P$. tectorius Park. sebagai bahan anyaman dalam membuat tikar, tas (noken), topi dan keranjang. Dengan berbagai kriteria ini, pemanfaatan serat alam dari daun $P$. tectorius Park. dapat menjadi sebuah produk serat alam yang lebih beragam sesuai dengan dimensinya.

\section{Kertas}

Kertas merupakan salah satu produk yang sangat dibutuhkan dalam kehidupan sehari-hari. Kertas yang digunakan dalam kehidupan sangat beragam, mulai dari kertas tulis, kertas foto, kertas koran, kertas cetak dan masih banyak lagi berbagai kriteria kertas yang dapat digunakan. Umumnya serat yang digunakan sebagai bahan baku kertas berasal dari kayu sehingga pemenuhan kebutuhan kertas akan memberikan dampak pada keberadaan hutan, terlebih jika bahan baku produk merupakan kayu yang diambil dari hutan. Daun $P$. tectorius Park. potensial dimanfaatkan sebagai bahan baku kertas karena mempunyai panjang serat dengan ukuran sedang, diameter serat dengan ukuran sedang dan tebal dinding serat yang termasuk tipis. Persyaratan Serat Kayu Sebagai Bahan Baku Pulp dan Kertas (Departemen Pertanian, 1976 yang disitasi Galugu, 2005).

Kertas yang potensial untuk dibuat dari bahan baku serat daun $P$. tectorius Park. adalah kertas koran dan kertas tulis. Kriteria dari bahan baku untuk kertas koran adalah mempunyai kekuatan sobek yang rendah dan tidak memerlukan derajat putih yang tinggi. Hasil penelitian 
menunjukkan bilangan muhlsteph dari serat daun P. tectorius Park. yang diambil dari Amban Pantai dan Pulau Mansinam termasuk dalam kelas 3. Semakin tinggi bilangan muhlsteph maka kekuatan sobek yang dihasilkan semakin rendah sehingga serat daun $P$. tectorius Park. dapat dimanfaatkan sebagai bahan baku pembuatan kertas koran.

Kertas tulis sebagai kertas yang sering digunakan dalam kegiatan pencatatan, mempunyai beberapa jenis yang banyak digunakan. Sebagai contoh terdapat kertas tulis yang mempunyai kekuatan tarik yang tinggi dan ada pula yang mempunyai kekuatan tarik sedang. Serat daun $P$. tectorius Park. Dapat dimanfaatkan sebagai kertas tulis dengan kriteria kertas tulis yang dapat dibuat yaitu kekuatan tarik dan sobek yang sedang dan tidak memerlukan derajat putih yang tinggi. Hasil penelitian menunjukkan bahwa kekuatan tarik dan sobek dari serat daun $P$. tectorius Park. termasuk sedang pada kelas kualitas III. Dengan demikian dapat dikatakan bahwa serat daun $P$. tectorius Park. Potensial dimanfaatkan sebagai kertas tulis.

Selain itu, serat daun $P$. tectorius Park. potensial dimanfaatkan sebagai bahan baku kertas sekuritas. Dimensi serat daun $P$. tectorius Park. Mempunyai kisaran nilai yang sama dengan dimensi serat dari daun nanas yang memiliki panjang 0,3-15 mm (ITS Surabaya, 2002 yang disitasi Sudjindro, 2012) dan diameter serat rata-rata $0,01 \mathrm{~mm}$ (Hidayat 2008). Menurut Sudjindro (2012), sifat ini memenuhi persyaratan untuk digunakan sebagai kertas sekuritas. Dari hasil penelitian ini, dimensi serat daun $P$. tectorius Park. baik yang berasal dari Amban Pantai maupun Pulau Mansinam memiliki kisaran nilai yang sama dengan serat urena, sehingga dapat dimanfaatkan juga sebagai bahan baku kertas sekuritas.

\section{Industri Tekstil}

Perkembangan rekayasa teknologi saat ini telah menciptakan berbagai bentuk bahan tenunan yang inovatif. Melalui pemanfaatan serat alam, industry pertekstilan telah menciptakan berbagai jenis pakaian yang dibutuhkan. Salah satu pemanfaatan serat alam yang dapat dimanfaatkan sebagai bahan baku tekstil adalah serat daun nanas (Hidayat 2008). Telah diketahui bahwa family Pandanaceae memiliki kedekatan dengan famili Agavaceae (Nanas). Dimensi Serat daun $P$. tectorius Park. memiliki kisaran nilai dimensi serat yang sama dengan daun nanas, sehingga dapat dikatakan serat daun $P$. tectorius Park. Dapat dimanfaatkan juga sebagai bahan baku tekstil. Tidak hanya sebagai bahan tenunan untuk industri tekstil, serat nanas juga telah dimanfaatkan sebagai bahan produk anyaman dengan rekayasa teknologi. Dengan pemanfaatan ini, serat $P$. tectorius Park. juga dapat menjadi salah satu produk anyaman serat alam.

Selain itu, bentuk produk lain dalam dunia industri tekstil adalah sepatu. Sebagai salah satu bagian dari produk sandang, sepatu menjadi kebutuhan masa kini khususnya sebagai alas kaki. Salah satu produk sepatu dari serat alam adalah menggunakan serat dari bambu. Rejeki (2014) dari hasil wawancaranya dengan Taufiq Rahman (pembuat sepatu dari serat bambu) mengatakan bahwa sepatu yang dibuat dari serat bambu dapat menghilangkan bau tidak sedap karena kapilaritas serat yang tinggi sehingga mudah untuk menyerap dan mengeluarkan air, anti bakteri, seratnya mampu menahan efek panas dan radiasi 
sehingga mampu menjaga kelembaban kulit. Hasil penelitian Fatriasari dan Hermiati (2008) menunjukkan bahwa serat dari bambu memiliki panjang serat diatas $2 \mathrm{~mm}$ dan memiliki tebal dinding serat tipis dan diameter lumen tebal. Dari hasil penelitian ini, dapat dikatakan serat dari daun $P$. tectorius Park. juga potensial untuk digunakan sebagai bahan baku pembuatan sepatu.

\section{Biokomposit}

Biokomposit merupakan gabungan atau pencampuran berbagai material alam membentuk suatu material baru. Komposit adalah material yang dibentuk dari gabungan dua atau lebih bahan baku penyusun melalui proses pencampuran. Karena bahan baku material penyusun berbeda-beda maka kekuatan yang dihasilkan mempunyai kekuatan yang berbeda-beda pula tergantung material kompositnya. Salah satu penerapan pembuatan biokomposit dalam perkembangan teknologi saat ini adalah di industri otomotif.

Industri otomotif sebagai salah satu bagian dalam perindustrian yang berkembang pesat saat ini, telah berusaha meningkatkan kebutuhan akan interior mobil. Salah satu pemanfaatannya adalah menggunakan komposisi serat alam dengan bahan komposit lainnya. Hal ini dikarenakan dengan pemanfaatan serat alam, sifat mekanik interior mobil lebih tinggi, biaya pembuatan relatif murah dan tahan terhadap kondisi lingkungan (Salahudin 2012). Serat alam tersebut salah satunya adalah serat dari daun $P$. tectorius Park. dimana menurut Salahudin (2012) dari hasil kajiannya, mengatakan bahwa sifat mekanik yang dihasilkan oleh serat daun $P$. tectorius Park. akan mampu memenuhi kebutuhan interior mobil.
Dengan demikian dapat dikatakan bahwa serat daun $P$. tectorius Park. potensial dimanfaatkan sebagai bahan baku interior mobil.

\section{DAFTAR PUSTAKA}

Fatiasari W. dan Hermiati E. 2008. Analisis morfologi serat dan fisiskimia pada enam jenis bambu sebagai bahan baku pulp dan kertas. Jurnal Ilmu dan Teknologi Hasil Hutan, Vol 1 (2): 67-72.

Frans AW. 2013. Waktu pemasakan yang tepat untuk mendapatkan serat Pandanus tectorius Park. dengan menggunakan metode forest Product Laboratory. Skripsi Fakultas Kehutanan Universitas Negeri Papua, Manokwari (tidak diterbitkan).

Galugu D. 2005. Dimensi serat kayu merbau (Intsia bijuga) dan ketapang pantai (Terminalia spp). Skripsi Fakultas Kehutanan Universitas Negeri Papua, Manokwari (tidak diterbitkan).

Hidayat P. 2008. Teknologi pemanfaatan serat daun nanas sebagai alternatif bahan baku tekstil. Jurnal Teknoin, Vol 13: (2): 31-35.

Husodo SB. 1997. Sifat anatomi pulp kraft dari jenis kayu Eucalyptus deglupta Blume. Tesis Pascasarjana Ilmu Kehutanan Universitas Mulawarman, Samarinda. (Tidak Diterbitkan).

IAWA. 1989. IAWA List of microscopic feature of hardwood indentification. IAWA Publisher, Leiden.

Kemeray SB. 2013. Jenis-jenis pandanus dan freycinetia berdasarkan karakter morfologi dan anatomi di pulau roswar kabupaten Teluk Wondama. Skripsi Fakultas Kehutanan 
Universitas Negeri Papua, Manokwari (tidak diterbitkan).

Rejeki S. 2014. Sepatu dari serat bambu. Kompas. Edisi Minggu, 6 Juli 2014. Hal. 32.

Renyaan J. 2009. Dimensi serat kayu tancang (Bruquiere gymnorrhiza). Skripsi Fakultas Kehutanan Universitas Negeri Papua, Manokwari (tidak diterbitkan).

Salahudin X. 2012. Kaji pengembangan serat daun pandan di kabupaten Magelang sebagai bahan komposit interior mobil. Jurnal UTM, Vol 37 (1): 121-133.

Sinaga NI dan DN. Irbayanti. 2004. Pemanfaatan tumbuhan dalam pembuatan alat-alat tradisional oleh wanita kampung Tarfia, Jayapura. Warta Wiptek Unipa. Manokwari.

Stone BC .1983. A guide to collecting Pandanaceae (Pandanus, Freycinetia and Sararanga). Ann. Missouri. Bot.Gard. 70:137 - 145 .

Sudjindro. 2011. Prospek serat alam untuk bahan baku kertas uang. Jurnal Perspektif, Vol 10 (2): 92-104. 